\title{
SUPPORTING INFORMATION On the Economics and Process Design of Renewable Butadiene from Biomass-Derived Furfural Anatoliy Kuznetsov ${ }^{1,2}$, Gaurav Kumar ${ }^{1,2}$, M. Alexander Ardagh ${ }^{1}$, Michael Tsapatsis ${ }^{3,4}$, Qi Zhang ${ }^{1}$, Paul J. Dauenhauer ${ }^{1,2 *}$
}

1. University of Minnesota, Department of Chemical Engineering and Materials Science, 421 Washington Ave. SE, Minneapolis, MN 55455

2. Center for Sustainable Polymers, University of Minnesota, 207 Pleasant Street SE, Minneapolis, MN 55455

3. Department of Chemical and Biomolecular Engineering \& Institute for NanoBioTechnology, Johns Hopkins University, 3400 N. Charles Street, Baltimore, MD 21218.

4. Johns Hopkins University, Applied Physics Laboratory, 11100 Johns Hopkins Road, Laurel, MD 20723

*Corresponding Author: hauer@umn.edu

\section{SI Contents:}

1) Process Stream Molar Flows

2) Process Unit Information

3) Economic Evaluation Parameters

4) Effect of MARR on Butadiene MSP

5) Effect of Tax Rate on Butadiene MSP

6) Effect of Plant Size on Butadiene MSP

7) Catalyst-related Calculations

8) Catalyst Cost Estimation

9) Design and Cost of Auxiliary Equipment, Membrane Module, Absorber, and Bubble-Column Reactor 


\section{1) Process Stream Molar Flows}

Table S1 $\mid$ Stream Data. Stream numbers correspond to labels in Figure 2.

\begin{tabular}{lccccccc}
\hline Molar Flow $\left(\mathrm{kmol} \mathrm{hr}^{-1}\right)$ & 1 & 2 & 3 & 4 & 5 & 6 & 7 \\
\hline Furfural & 102.72 & 102.72 & 5.14 & 5.14 & 0.11 & 0.00 & 0.00 \\
Furan & 0.00 & 0.00 & 96.12 & 96.12 & 96.12 & 0.28 & 0.28 \\
THF & 0.00 & 0.00 & 0.00 & 0.00 & 0.00 & 0.00 & 0.00 \\
Furfuryl alcohol & 0.19 & 0.19 & 1.65 & 1.65 & 0.00 & 0.00 & 0.00 \\
Hydrogen & 204.93 & 204.93 & 203.47 & 203.47 & 203.47 & 203.47 & 1.54 \\
Water & 0.00 & 0.00 & 0.00 & 0.00 & 0.00 & 0.00 & 0.00 \\
Butadiene & 0.00 & 0.00 & 0.00 & 0.00 & 0.00 & 0.00 & 0.00 \\
Carbon monoxide & 6.70 & 6.70 & 102.82 & 102.82 & 102.82 & 101.98 & 95.28 \\
1-Butene & 0.00 & 0.00 & 0.00 & 0.00 & 0.00 & 0.00 & 0.00 \\
Formaldehyde & 0.00 & 0.00 & 0.00 & 0.00 & 0.00 & 0.00 & 0.00 \\
Heavy impurities ${ }^{a}$ & 0.00 & 0.00 & 0.00 & 0.00 & 0.00 & 0.00 & 0.00 \\
Propene & 0.00 & 0.00 & 0.00 & 0.00 & 0.00 & 0.00 & 0.00 \\
Temperature $\left({ }^{\circ} \mathrm{C}\right)$ & 40.2 & 137.0 & 280.0 & 147.0 & 7.0 & -80.0 & 60.0 \\
Pressure $(\mathrm{atm})$ & 1.0 & 1.0 & 1.0 & 1.0 & 1.0 & 1.0 & 35.5 \\
\hline
\end{tabular}

${ }^{a}$ Heavy side products of the dehydra-decyclization reactions have not been well characterized. In Aspen, they were modeled as 2-ethyl-2-hexenal to simplify reaction stoichiometry.

\begin{tabular}{lccccccc}
\hline Molar Flow $\left(\mathrm{kmol} \mathrm{hr}^{-1}\right)$ & 8 & 9 & 10 & 11 & 12 & 13 & 14 \\
\hline Furfural & 0.00 & 5.02 & 2.72 & 2.30 & 0.11 & 0.00 & 0.11 \\
Furan & 0.00 & 0.00 & 0.00 & 0.00 & 95.841 & 0.00 & 0.00 \\
THF & 0.00 & 0.00 & 0.00 & 0.00 & 0.00 & 0.00 & 95.841 \\
Furfuryl alcohol & 0.00 & 1.65 & 0.19 & 1.46 & 0.00 & 0.00 & 0.00 \\
Hydrogen & 201.93 & 0.00 & 0.00 & 0.00 & 0.00 & 191.78 & 0.12 \\
Water & 0.00 & 0.00 & 0.00 & 0.00 & 0.00 & 0.00 & 0.00 \\
Butadiene & 0.00 & 0.00 & 0.00 & 0.00 & 0.00 & 0.00 & 0.00 \\
Carbon monoxide & 6.70 & 0.00 & 0.00 & 0.00 & 0.84 & 0.00 & 0.84 \\
1-Butene & 0.00 & 0.00 & 0.00 & 0.00 & 0.00 & 0.00 & 0.00 \\
Formaldehyde & 0.00 & 0.00 & 0.00 & 0.00 & 0.00 & 0.00 & 0.00 \\
Heavy impurities & 0.00 & 0.00 & 0.00 & 0.00 & 0.00 & 0.00 & 0.00 \\
Propene & 0.00 & 0.00 & 0.00 & 0.00 & 0.00 & 0.00 & 0.00 \\
Temperature $\left({ }^{\circ} \mathrm{C}\right)$ & 60.0 & 162.3 & 161.5 & 163.1 & 100.0 & 25.0 & 100.0 \\
Pressure $($ atm $)$ & 5.4 & 1.0 & 1.0 & 1.0 & 22.2 & 22.2 & 22.2 \\
\hline
\end{tabular}




\begin{tabular}{lccc}
\hline Molar Flow $\left(\mathrm{kmol} \mathrm{hr}^{-1}\right)$ & 15 & 16 & 17 \\
\hline Furfural & 0.11 & 0.11 & 0.11 \\
Furan & 0.00 & 0 & 0 \\
THF & 116.30 & 22.68 & 22.68 \\
Furfuryl alcohol & 0.00 & 0.00 & 0.00 \\
Hydrogen & 0.12 & 0.12 & 0.12 \\
Water & 4.73 & 91.08 & 91.08 \\
Butadiene & 0.00 & 75.83 & 75.83 \\
Carbon monoxide & 0.84 & 0.84 & 0.84 \\
1-Butene & 1.34 & 5.87 & 5.87 \\
Formaldehyde & 0.03 & 1.31 & 1.31 \\
Heavy impurities & 0.00 & 5.99 & 5.99 \\
Propene & 0.00 & 1.28 & 1.28 \\
Temperature $\left({ }^{\circ} \mathrm{C}\right)$ & 415.0 & 425.0 & 70.3 \\
Pressure $($ atm $)$ & 1.0 & 1.0 & 1.0 \\
\hline & & & \\
\hline Molar Flow $\left(\mathrm{kmol} \mathrm{hr}^{-1}\right)$ & 22 & 23 & 24 \\
\hline Furfural & 0.11 & 0.00 & 0.11 \\
Furan & 0.00 & 0.00 & 0.00 \\
THF & 22.66 & 20.46 & 2.20 \\
Furfuryl alcohol & 0.00 & 0.00 & 0.00 \\
Hydrogen & 0.00 & 0.00 & 0.00 \\
Water & 90.86 & 4.73 & 86.13 \\
Butadiene & 0.00 & 0.00 & 0.00 \\
Carbon monoxide & 0.00 & 0.00 & 0.00 \\
1-Butene & 1.61 & 1.34 & 0.27 \\
Formaldehyde & 0.03 & 0.027 & 0.00 \\
Heavy impurities & 5.99 & 0.00 & 5.99 \\
Propene & 0.00 & 0.00 & 0.00 \\
Temperature $\left({ }^{\circ} \mathrm{C}\right)$ & 66.8 & 58.0 & 83.0 \\
Pressure $($ atm $)$ & 1.0 & 1.0 & 1.0 \\
\hline
\end{tabular}

Kuznetsov, et al. 


\section{2) Process Unit Information}

Table S2-A | Distillation Column Heat Duties

\begin{tabular}{lcccc}
\hline Column & D-1 & D-2 & D-3 & D-4 \\
\hline Condenser Duty (MW) & -40.01 & -0.35 & -1.43 & -0.35 \\
Reboiler Duty (MW) & 39.30 & 0.39 & 0.60 & 0.39 \\
\hline
\end{tabular}

Table S2-B | Heater and Cooler Heat Duties

\begin{tabular}{lcc}
\hline Unit & HX-3 & HX-5 \\
\hline Heat Duty (MW) & -0.30 & 0.02 \\
\hline
\end{tabular}

Table S2-C | Reactor and Flash Tank Heat Duties

\begin{tabular}{lllll}
\hline Unit & R-1 & R-2 & R-3 & F-1 \\
\hline Heat Duty (MW) & 0.16 & -4.19 & 1.21 & -1.21 \\
\hline
\end{tabular}

Table S2-D | Heat Exchanger Duties

\begin{tabular}{lccc}
\hline Unit & HX-1 & HX-2 & HX-4 \\
\hline Heat Duty (MW) & 0.74 & 0.54 & 2.47 \\
\hline
\end{tabular}

Table S2-E | Pump and Compressor Duties

\begin{tabular}{lcc}
\hline Unit & P-1 & C-1 \\
\hline Duty $(\mathrm{kW})$ & 15.21 & 1188.06 \\
\hline
\end{tabular}

Table S2-F $\mid$ Process Unit Aspen Modules and Total Installed Costs.

\begin{tabular}{lcc}
\hline Unit & Module & Cost (\$MM) \\
\hline HX-1 & HeatX & 0.42 \\
HX-2 & HeatX & 0.29 \\
HX-3 & Heater & 0.57 \\
HX-4 & HeatX & 0.51 \\
HX-5 & Heater & 0.11 \\
P-1 & Pump & 0.11 \\
C-1 & Compr & 7.74 \\
R-1 & RStoic & 1.76 \\
R-2 $^{\text {a }}$ & RStoic & 2.09 \\
R-3 & RStoic & 1.03 \\
D-1 & RadFrac & 22.86 \\
D-2 & RadFrac & 4.54 \\
D-3 & RadFrac & 10.4 \\
D-4 & RadFrac & 2.05 \\
F-1 & Flash2 & 0.49 \\
A-1 & Extract & 1.49 \\
M-1 & Sep2 & 0.93 \\
\hline
\end{tabular}

${ }^{\mathrm{a}}$ Reactor costs shown include both parallel reactors. 


\section{3) Economic Evaluation Parameters}

Table S3 | Parameters for Economic Analysis.

\begin{tabular}{ll}
\hline Plant Lifetime & 30 years \\
Minimum Annual Rate of Return (MARR) & $10 \%$ \\
Tax Rate & $35 \%$ \\
Annual Operating Time & 8000 hours \\
Working Capital & $5 \%$ of total capital investment \\
Depreciation Method & $150 \%$ declining balance MACR \\
Recovery Period & 5 years \\
\hline
\end{tabular}

MARR: According to McKinsey \& Company, commodity chemicals (such as butadiene) typically yield a rate of return between $6 \%$ and $10 \% .{ }^{1}$ A conservative value of $10 \%$ was chosen for this work.

Depreciation Method and Recovery Period: IRS Publication 946 stipulates that chemical plants have a 5year recovery period and allows the use of a 150\% Modified Accelerated Cost Recovery (MACR) method. ${ }^{2}$ The MACR method is a declining balance method which switches to straight-line depreciation once the straight-line method provides a greater deduction. 


\section{4) Effect of MARR on Butadiene MSP}

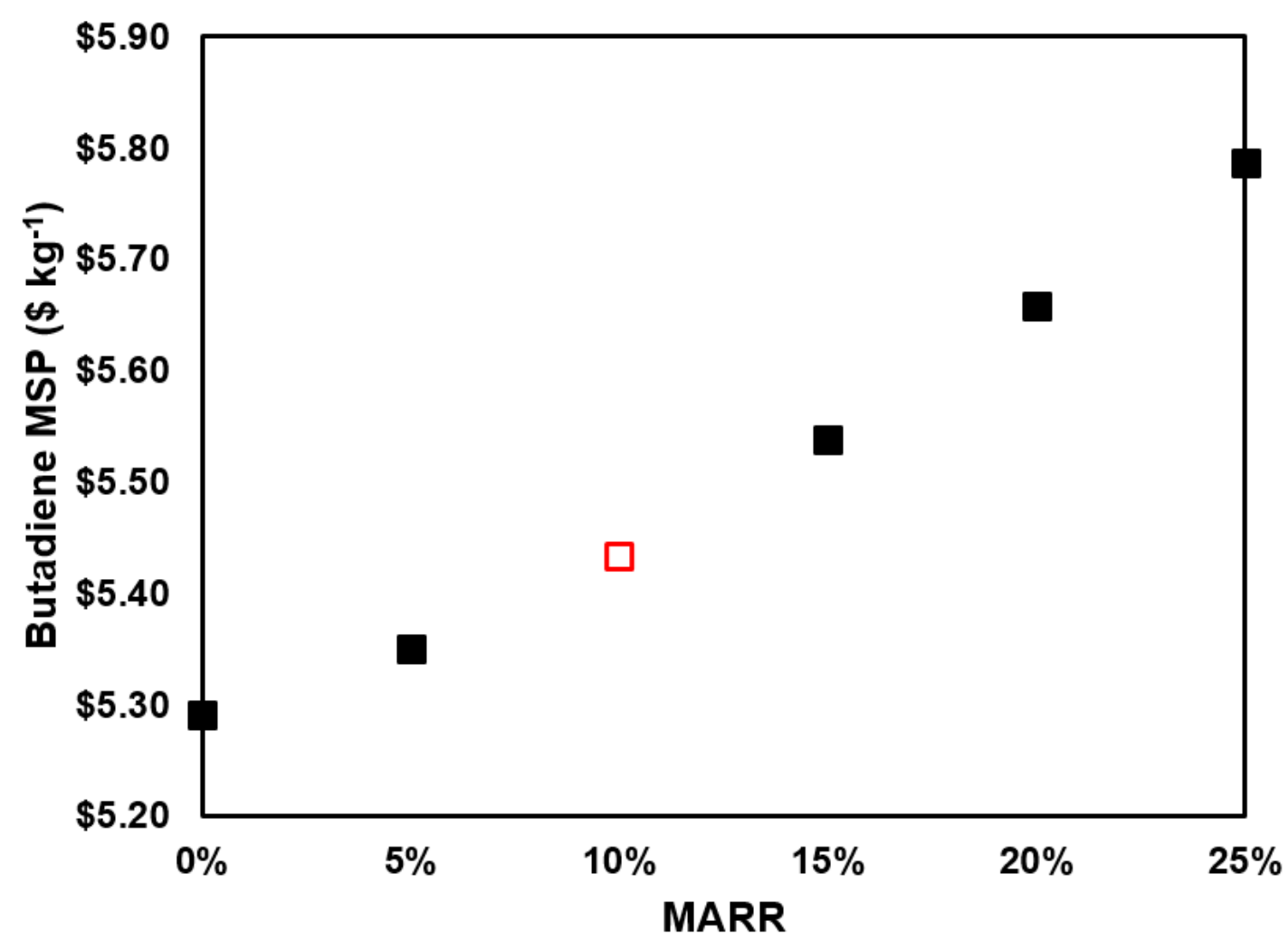

Figure S1 | Effect of MARR on Butadiene MSP. Plant lifetime: 30 years, tax rate: $35 \%$, process scale:

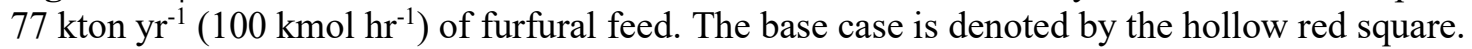


5) Effect of Tax Rate on Butadiene MSP

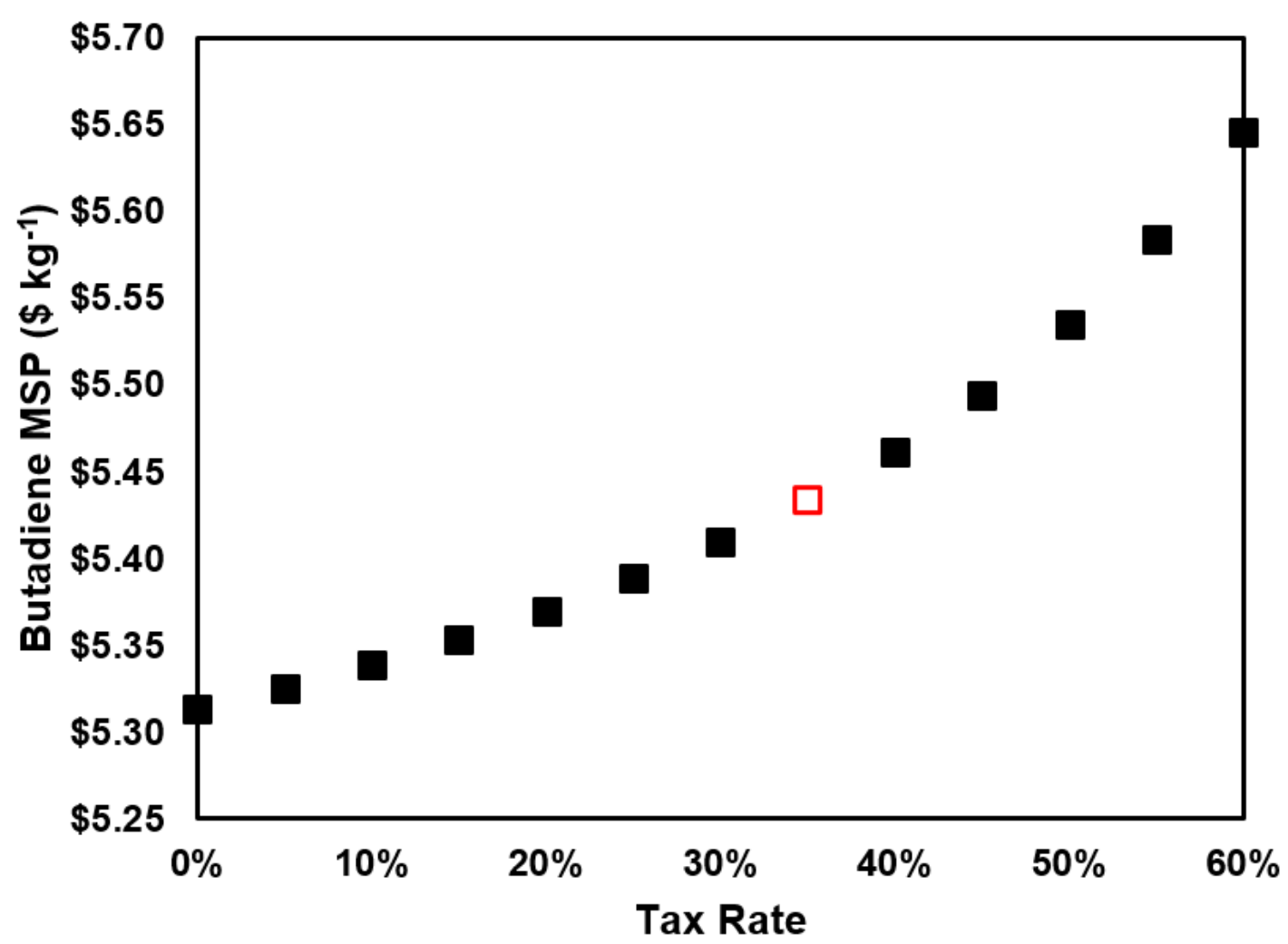

Figure S2 | Effect of Tax Rate on Butadiene MSP. Plant lifetime: 30 years, MARR: 10\%, process

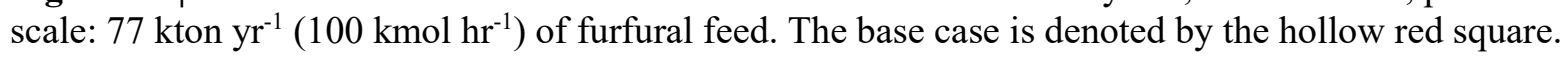


6) Effect of Plant Size on Butadiene MSP

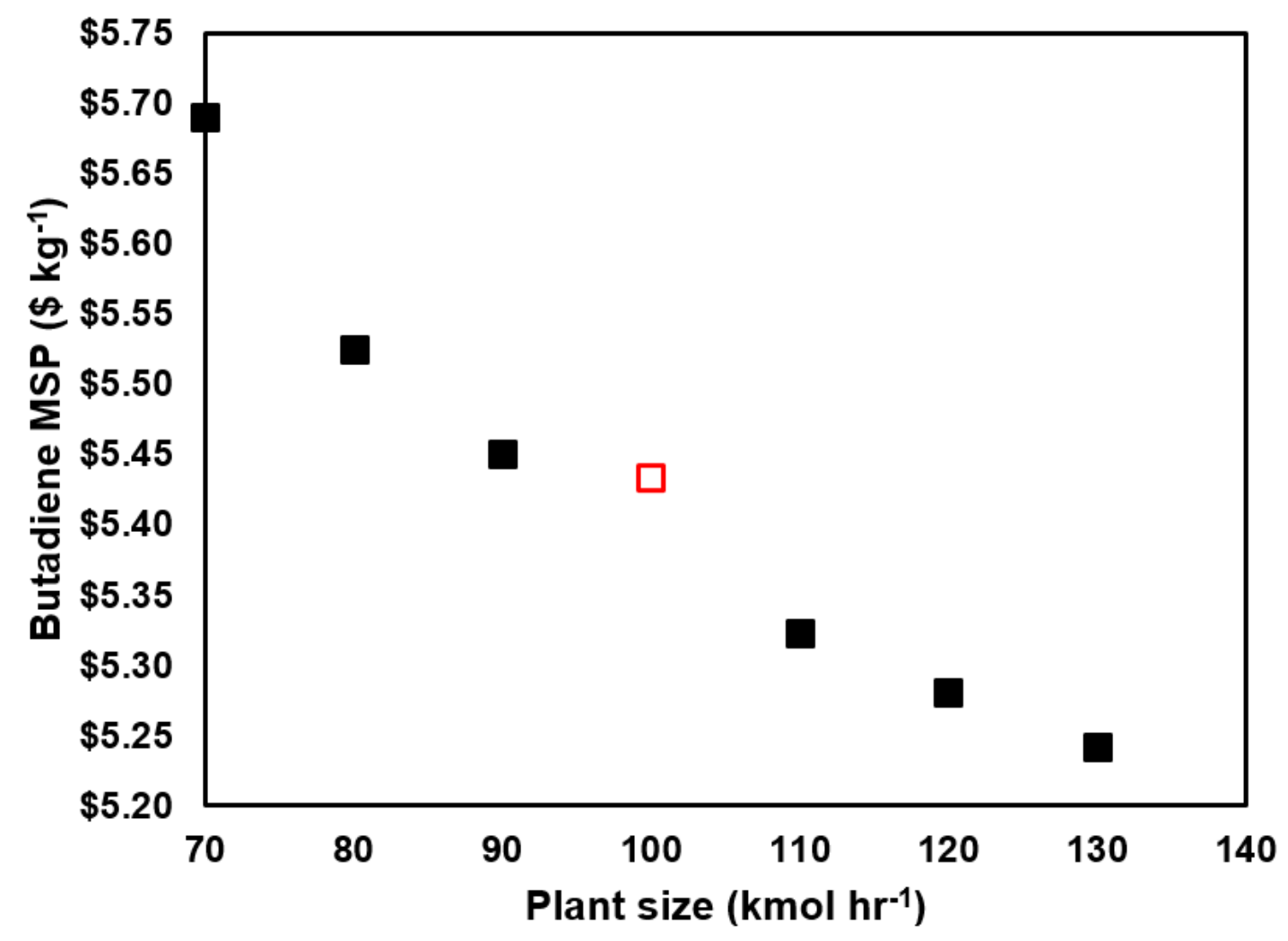

Figure S3 | Effect of Plant Size on Butadiene MSP. Plant lifetime: 30 years, MARR: 10\%, tax rate: $35 \%$. The base case is denoted by the hollow red square. 


\section{7) Catalyst-related calculations}

\subsection{Decarbonylation Catalyst amount}

US Patent $8,404,871$ reports $98 \%$ selectivity to furan at $95 \%$ conversion using a $0.5 \mathrm{wt} . \%$ Pd catalyst that has been treated with cesium carbonate. ${ }^{3}$ After 437 hours on stream, $34.257 \mathrm{~kg}$ furan had formed per g Pd. The catalyst activity is therefore

$$
\frac{\left(\frac{34527 \mathrm{~g} \mathrm{furan}}{437 \mathrm{hr}}\right)\left(\frac{1 \mathrm{~mol} \text { furan }}{68.07 \mathrm{~g}}\right)}{1 \mathrm{gPd}\left(\frac{200 \mathrm{gcatalyst}}{1 \mathrm{gPd}}\right)}=5.80 \times 10^{-3} \frac{\mathrm{mol} \text { furan }}{\text { gcat } \mathrm{hr}}
$$

For a furan production rate of $96 \mathrm{kmol} \mathrm{hr}^{-1}$, and accounting for $98 \%$ selectivity, the amount of catalyst needed is then

$$
\frac{96000 \mathrm{~mol} \text { furan } \mathrm{hr}^{-1}}{\left(5.80 \times 10^{-3} \frac{\mathrm{mol} \mathrm{furan}}{\mathrm{gcat} \mathrm{hr}}\right) 0.98}=1.69 \times 10^{7} \mathrm{~g}
$$

or 16.9 tons.

\subsection{Hydrogenation Catalyst amount}

Godawa et al. report that a $5 \mathrm{wt} . \% \mathrm{Pd} / \mathrm{C}$ catalyst exhibits a turnover rate of $2375 \mathrm{hr}^{-1}$ at full furan conversion. ${ }^{4}$ Therefore, the catalyst activity is

$$
\left(\frac{2375 \mathrm{~mol}}{1 \mathrm{~mol} \mathrm{Pd} \cdot \mathrm{hr}}\right)\left(\frac{1 \mathrm{~mol} \mathrm{Pd}}{106.42 \mathrm{gPd}}\right)\left(\frac{1 \mathrm{gPd}}{20 \mathrm{gcat}}\right)=1.12 \frac{\mathrm{mol}}{\mathrm{gcat} h r}
$$

For a furan flow rate of $96 \mathrm{kmol} \mathrm{hr}^{-1}$, the amount of catalyst needed is

or $85.7 \mathrm{~kg}$.

$$
\frac{96000 \mathrm{~mol} \mathrm{hr}^{-1}}{1.12 \frac{\mathrm{mol}}{\mathrm{gcat} \mathrm{hr}}}=8.57 \times 10^{4} \mathrm{~g}
$$

\subsection{Dehydra-Decyclization Catalyst amount}

At a weight hourly space velocity (WHSV) of $0.092 \mathrm{~g} \mathrm{THF}_{\text {gcat }}{ }^{-1} \mathrm{hr}^{-1}$, a conversion of $80.5 \%$ was experimentally observed. The THF conversion rate is then

$$
0.805\left(\frac{0.092 \mathrm{~g} \mathrm{THF}}{1 \mathrm{gcat} \cdot \mathrm{hr}}\right)\left(\frac{1 \mathrm{~mol} \mathrm{THF}}{72.11 \mathrm{gTHF}}\right)=1.03 \times 10^{-3} \frac{\mathrm{mol}}{\mathrm{gcat} h r}
$$

The THF consumption rate is $80.5 \%$ of the inlet flow rate of $116,300 \mathrm{~mol} \mathrm{THF} \mathrm{hr}^{-1}$, or 93,600 mol THF $\mathrm{hr}^{-1}$. Therefore, the amount of catalyst needed is: 


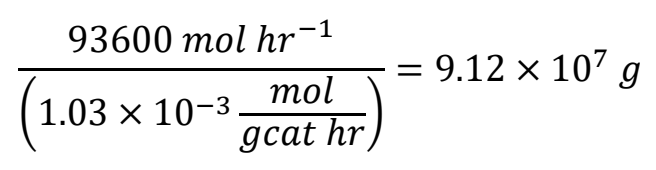

or 91.2 tons. All fixed-bed reactors were sized using an estimated catalyst density of $1000 \mathrm{~kg} \mathrm{~m}^{-3}$.

\subsection{Dehydra-Decyclization Catalyst lifetime calculations}

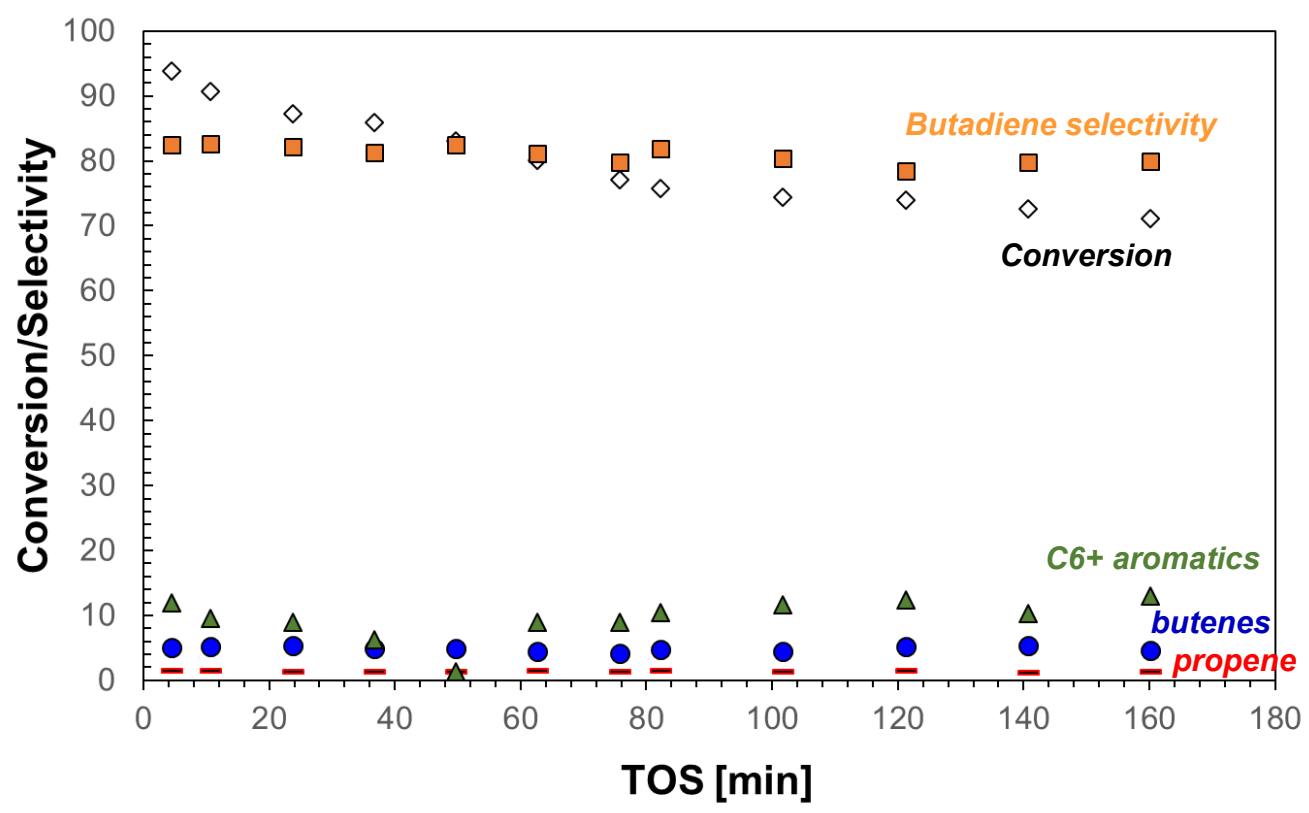

Figure S4 | Reaction details for the THF dehydra-decyclization reactor design. THF conversion, and product selectivities $(\% \mathrm{C})$ to butadiene, propene, butenes, and $\mathrm{C} 6+$ aromatics fraction, as a function of time-on-stream for P-SPP (Reaction conditions: $\mathrm{T}=425 \mathrm{deg} \mathrm{C}, \mathrm{p}_{\mathrm{THF}}=4.6 \mathrm{torr}, \mathrm{WHSV}=0.09 \mathrm{~h}^{-1}$, Carbon balances closed to within $\pm 10 \%$ )

Figure S4 shows the catalytic performance of the dehydra-decyclization catalyst. The catalyst deactivated with time-on-stream, and the conversion decreased from $92 \%$ to $71 \%$ within the first three hours of keeping the catalyst on-stream. Notably, the butadiene selectivities remain nearly invariant with deactivation. While the conversion and product selectivities at $\mathrm{t}=100$ minutes were used in the process simulation of reactor R-3, a first order deactivation model was used to extract a deactivation rate constant, which in turn was used to validate the choice of catalyst lifetime chosen in this work.

$$
\begin{gathered}
\frac{d X_{i}}{d t}=-k X_{i} ; \mathrm{BCs}: X_{i}(t=0)=X_{i, o} \text { and } X_{i}(t \rightarrow \infty)=0 \\
X_{i}(t)=X_{i, 0} \exp ^{-k t}
\end{gathered}
$$

where $X_{i, 0}$ is the initial fractional conversion $(=92 \%)$, and $k$ is the deactivation rate constant $\left(\mathrm{h}^{-1}\right)$. Fitting the experimental data to this model results in a deactivation rate constant of $0.12 \mathrm{~h}^{-1}$. Assuming that butadiene selectivities remain invariant and the catalyst lifetime is defined as time till conversions drop below $5 \%$, this results in a catalyst lifetime of $\sim 25$ hours, validating our choice of a 24 hours as dehydradecyclization catalyst lifetime. 


\section{8) Catalyst Cost Estimation}

The step method in CatCost V1.0.0 was used to estimate the synthesis cost of the first two catalysts in the process; the cost of the third catalyst was taken directly to be $\$ 2.81 \mathrm{~kg}^{-1}$ from the work of Lundberg and co-workers. ${ }^{5}$ CatCost calculates a third-party synthesis campaign cost based on the raw materials needed, the type of process, and the scale of the campaign. The economic benefit of recovering metal from the spent catalyst was also considered, assuming a 3\% metal loss during use and a $2.5 \%$ metal loss during recovery. Parameters used in the CatCost analysis are presented in Table S-4.

Table S-4 | CatCost Parameters and Results.

\begin{tabular}{lccc}
\hline Catalyst & Synthesis campaign size (tons) & Process Template & Cost per Campaign \\
\hline $0.5 \% \mathrm{Pd} /$ alumina (R-1) & 16.9 & $\begin{array}{c}\text { Metal (PGM) on } \\
\text { Metal Oxide }\end{array}$ & $\$ 3,617,847$ \\
$5 \% \mathrm{Pd} / \mathrm{C}(\mathrm{R}-2)$ & 0.0857 & $\begin{array}{c}\text { Metal (PGM) on } \\
\text { Carbon }\end{array}$ & $\$ 308,287$ \\
& & & \\
\hline
\end{tabular}

The above costs do not include the discount from the sale of recovered metal at the end of the catalyst lifetime. Assuming that palladium can be recovered from both catalysts, and with an estimated bulk density of $1000 \mathrm{~kg} \mathrm{~m}^{-3}$ for the $\mathrm{Pd} /$ alumina catalyst and $560 \mathrm{~kg} \mathrm{~m}^{-3}$ for the $\mathrm{Pd} / \mathrm{C}$ catalyst, CatCost estimates that the spent catalyst value per synthesis campaign is $\$ 40,795$ for the Pd/alumina catalyst and $\$ 190$ for the $\mathrm{Pd} /$ carbon catalyst. For the fixed-bed reactor (R-1), CatCost estimates a 3\% loss of metal during use, and for the bubble-column reactor (R-2), modeled as a slurry/fluidized-bed reactor in CatCost, a 5\% loss of metal during use is assumed. A further $2.5 \%$ loss of metal due to refining is assumed.

The above costs are for the amount of catalyst needed in one reactor; in the economic analysis, it was assumed that twice this amount was purchased at the end of each catalyst lifetime to account for the parallel reactors. For process scales other than the base case, the catalyst cost was calculated using the same approach to account for economies of scale in catalyst manufacturing. 


\section{9) Design and Cost of Auxiliary Equipment, Membrane Module, Absorber, and Bubble-Column Reactor}

Capital costs for all process units except the bubble column reactor and cellulose acetate membrane module were estimated using Aspen Economic Analyzer (V8.6 Aspen Technology). Aspen Economic Analyzer provides an estimate of the total installed cost of equipment accounting for direct and indirect costs. This section provides details on the estimation of capital costs for the remaining process and auxiliary equipment.

\section{Storage Vessels}

Storage tanks for furfural and butadiene were sized to hold one week's worth of each chemical at ambient pressure; the hydrogen storage tank was sized to hold $24 \mathrm{~h}$ worth of hydrogen at a pressure of 700 bar and a density of $42 \mathrm{~kg} \mathrm{~m}^{-3} .{ }^{6}$ Storage units were sized using correlations given by Seider. ${ }^{7}$

Table S-5 | Storage Tank Information.

\begin{tabular}{lccc}
\hline Chemical & Vessel Type & Volume $\left(\mathrm{m}^{3}\right)$ & Cost $(\$)$ \\
\hline Furfural & Floating Roof & 13773 & $\$ 1,007,000$ \\
Hydrogen & Pressure Vessel & 225 & $\$ 1,110,000$ \\
Butadiene & Floating Roof & 1048 & $\$ 273,000$ \\
\hline
\end{tabular}

A sample calculation for the furfural tank cost is given below (note that the correlation is given in units of gallons):

$$
\text { Purchase cost }=475 *\left(3.64 \times 10^{6} \mathrm{gal}\right)^{0.507}=\$ 1,007,129
$$

The installed cost of storage equipment was calculated from the purchase cost by multiplying the purchase cost by the average bare-module factor for other plant equipment. The sizes of the storage vessels were calculated in this manner for every process scale considered.

\section{Wastewater Treatment}

The cost to remove organic material from streams 21 (spent solvent) and 24 (the bottoms of column D-4) was calculated using correlations provided by Seider. ${ }^{7}$

Table S-6 | Wastewater Treatment Information.

\begin{tabular}{lcccc}
\hline Stream & $\begin{array}{c}\text { Volumetric Flow } \\
\text { Rate }\left(\text { gal } \mathrm{min}^{-1}\right)\end{array}$ & $\begin{array}{c}\text { Mass Flow Rate of } \\
\text { Organic }\left(\mathrm{kg} \mathrm{hr}^{-1}\right)\end{array}$ & Capital Cost $(\$)$ & $\begin{array}{c}\text { Yearly Cost }(\$ \\
\left.\mathrm{yr}^{-1}\right)\end{array}$ \\
\hline 21 & 12.9 & 982 & $\$ 208,200$ & $\$ 2,591,900$ \\
24 & 8.7 & 472 & $\$ 139,900$ & $\$ 1,246,000$ \\
\hline
\end{tabular}

A sample calculation for the cost of treating streams 21 and 24 is given below (the correlation is given in units of gal $\mathrm{min}^{-1}$ for estimating capital cost, and $\mathrm{kg} \mathrm{hr}^{-1}$ for estimating operating cost):

$$
\begin{gathered}
\text { Capital cost }=48760\left((12.9+8.7) \mathrm{gal} \mathrm{min}^{-1}\right)^{0.64}=\$ 348,124 \\
\text { Operating cost }=\left(\$ 0.33 \mathrm{~kg}^{-1}\right)\left((982+472) \mathrm{kg} \mathrm{hr}^{-1}\right)\left(8000 \mathrm{hr}^{-1}\right)=\$ 3,838,560
\end{gathered}
$$

The installed cost of wastewater treatment was calculated from the purchase cost by multiplying the purchase cost by the average bare-module factor for other plant equipment. The capital cost of the wastewater treatment system was calculated in this manner for every process scale considered. 


\section{Carbon Monoxide Boiler}

Assuming the total combustion of the species in stream 7 with a stoichiometric feed of air at 1400 ${ }^{\circ} \mathrm{F},{ }^{8}$ along with $80 \%$ heat recovery in the production of 100 psia steam, the boiler generates $2.0 \mathrm{MW}$ of useful heat. This is equivalent to $9658 \mathrm{~kg} \mathrm{hr}^{-1}$ of steam, or $\$ 1.11 \mathrm{M}$ per year in offset steam costs using a steam cost of $\$ 0.0179 \mathrm{~kg}^{-1}$ as in Table 1 . The installed cost of the boiler was estimated to be $\$ 1.2 \mathrm{M}$ based on values for a $2.5 \mathrm{MW}$ natural gas boiler given by Ghafghazi and co-workers (indexed to 2019 using the Chemical Engineering Plant Cost Index). ${ }^{9}$

\section{Cellulose Acetate Membrane Module}

The cellulose acetate membrane module was designed based on the results of DiMartino and coworkers, who used a two-stage module to produce a permeate of $97 \mathrm{~mol} \%$ hydrogen at $4.5 \mathrm{barg}$ and a reject of $98 \%$ carbon monoxide from a feed gas of $52 \%$ hydrogen. ${ }^{10}$ The inlet stream in this process is $66 \%$ hydrogen, but the same purity specifications were assumed for the effluent streams. The membrane area necessary was calculated using a mass balance for a well-mixed separation by gas membrane: ${ }^{11}$

$$
A=\frac{f_{P} x_{p}}{\left(\frac{P}{t}\right)\left(p_{H} x_{f}-p_{L} x_{p}\right)}
$$

where $A$ is the membrane area in $\mathrm{cm}^{2}, f_{P}$ is the permeate flow rate in $\mathrm{cm}^{3} \mathrm{STP} \mathrm{s}{ }^{-1}, x_{p}$ and $x_{f}$ refer to the permeate and feed mole fractions of hydrogen respectively, $P / t$ is the hydrogen permeability through cellulose acetate in $\mathrm{cm}^{3} \mathrm{STP} \mathrm{cm}^{-2} \mathrm{~s}^{-1} \mathrm{~atm}^{-1}$, and $p_{H}$ and $p_{L}$ are the pressures in atm of the high-

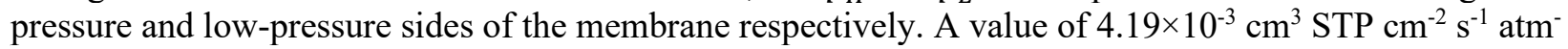
${ }^{1}$ for $P / t$ was used based on experiments at $60{ }^{\circ} \mathrm{C}$ conducted by Lee and co-workers. ${ }^{12}$ The total membrane area was then calculated as:

$$
A=\frac{\left(1.299 \times 10^{6} \mathrm{~cm}^{3} S T P \mathrm{~s}^{-1}\right)(0.97)\left(10^{-4} \mathrm{~m}^{2} \mathrm{~cm}^{-2}\right)}{\left(4.19 \times 10^{-3} \mathrm{~cm}^{3} S T P \mathrm{~cm}^{-2} \mathrm{~s}^{-1} \mathrm{~atm}^{-1}\right)(35.5 \mathrm{~atm}(0.66)-5.4 a \mathrm{tm}(0.97)}=1700 \mathrm{~m}^{2}
$$

The total installed membrane module cost was estimated as $\$ 547 \mathrm{~m}^{-2}$ as suggested by Seider. ${ }^{7}$

\section{Bubble-Column Reactor}

The bubble-column reactor was designed as a vertical pressure vessel made from low-alloy SA387B steel to mitigate embrittlement, with a 50-minute residence time (volume of $5.8 \mathrm{~m}^{3}$ ) based on the results of Godawa and co-workers. ${ }^{13}$ A wall thickness of $8 \mathrm{~mm}$, I.D. of $1.56 \mathrm{~m}$, length of $3 \mathrm{~m}$, and purchase cost of $\$ 251,000$ per reactor were estimated using the guidelines proposed by Seider, and a factor of 4.16 was used to estimate the total installed cost from the purchase cost. ${ }^{7}$

\section{Absorber column}

The absorption column was modeled as a 20 -stage gas-liquid contactor using the Extract module in Aspen with a temperature specification of $6^{\circ} \mathrm{C}$. Its installed cost was estimated by Aspen Economic Analyzer. 


\section{References}

1. McKinsey \& Company, Mehdi Miremadi, Christopher Musso, and Jonas Oxgaard. "Chemical innovation: An investment for the ages". McKinsey on Chemicals May 2013.

2. "How to Depreciate Property." U.S. Internal Revenue Service, 2018. Available from: https://www.irs.gov/pub/irs-pdf/p946.pdf. Accessed July 8, 2019.

3. Documents, U. S. P.; Under, F.; Conditions, M. US 8.404.871 B2. 2013, 2 (12).

4. Godawa, C.; Rigal, L.; Gaset, A. Palladium catalyzed hydrogenation of furan: optimization of production conditions for tetrahydrofuran. Resour. Conserv. Recycl. 1990, 3 (4), 201-216.

5. Lundberg, D. J.; Lundberg, D. J.; Zhang, K.; Dauenhauer, P. Process Design and Economic Analysis of Renewable Isoprene from Biomass via Mesaconic Acid. ACS Sustainable Chem. Eng. 2019, 7, 5576-5586.

6. Air Liquide. "Storing Hydrogen". https://energies.airliquide.com/resources-planethydrogen/howhydrogen-stored. Accessed July 20, 2019.

7. Seider, W. D.; Lewin, D. R.; Seader, J. D.; Widagdo, S.; Gani, R.; Ng, K. M. Product and Process Design Principles, 4th ed.; Wiley: New York, 2017.

8. Campbell, O. F.; Decker, W. H. United States Patent Office \#2753925A. 1956.

9. Ghafghazi, S.; Sowlati, T.; Sokhasanj, S.; Melin, S. Techno-economic analysis of renewable energy source options for a district heating project. Int. J. Energ. Res. 2010 (34) 1109-1120.

10. DiMartino, S. P.; Glazer, J. L.; Houston, C. D.; Schott, M. E. Hydrogen/carbon monoxide separation with cellulose acetate membranes. Gas Sep. Purif. 1988, 2 (3), 120-125.

11. Geankoplis, C. Transport Processes and Unit Operations. $3^{\text {rd }}$ edition, 1993. Prentice Hall International.

12. Lee, K. I.; Shim, I. W.; Hwang, S. T. The effects of transition metal complexes on the permeation of small gas molecules through cellulose acetate membranes. J. Membrane Sci. 1991 (60) 207218.

13. Godawa, C.; Rigal, L.; Gaset, A. Palladium catalyzed hydrogenation of furan: optimization of production conditions for tetrahydrofuran. Resour. Conserv. Recycl. 1990, 3 (4), 201-216. 